\title{
Beneficial Economics of Youth and Their Role Towards Regional Development in the Palm Planters Area at Bandar Pasir Mandoge, Asahan Regency, Indonesia
}

\author{
Sabam S. Manurung \\ Graduate School Pasca Sarjana University of Sumatera Utara \\ Medan, 20228, Indonesia \\ Sabam.fisipusu@gmail.com
}

\begin{abstract}
Youth are part of a community that has always participated in the process of development. The aim of this research to examines the factors that affect welfare of youth in the Palm planters area and their role towards regional development through economic activities in the sector of management of palm plantation in Bandar Pasir Mandoge, Asahan Regency, Indonesia. Through quantitative research methods with multiple linear regression analysis obtained two different conclusions. Simultaneous test result (f-test) obtained the all of variables who the factor that affect welfare influence the welfare of youth. While partially ( $t$-test) obtained economic status variable $\left(X^{1}\right)$, experience $\left(X^{3}\right)$ and social status $\left(X^{5}\right)$-influence on the welfare of youth, but the education variable $\left(X^{2}\right)$ and youth organizations $\left(X^{4}\right)$ does not affect the welfare of youth. In addition, the role of youth as workers, farmers and entrepreneurs have been able to push the income and purchasing power. But the welfare inequality still high enough among youth based on his profession as Palm planters. This is because the youth do not have the same opportunity to enhance the welfare himself.
\end{abstract}

Key word: The Welfare of Youth, Role of Youth, Regional Development, Role of Youth in the Palm Planters Area.

\section{INTRODUCTION}

Development is the continuous effort made to improve the live of people and nation which have not been good, or to improve an already good life for better (Subejo, 2005). While according to Theresia (2014), development is the process of change in order to achieve the level of welfare of society that wished and carry out the construction of it. Furthermore according to Badrudin (2012) economic development can be successful if the level of welfare of society the better, since the successes of economic development without a welfare enhancement included then it will result in gaps in the community. On the basis of State, it's understood that the development and welfare of society in the unity of the system of mutual influence.

The development has also a process that conducted by many communities, one communities who did the development is youth. As declarated by the President of Indonesia at the Youth Congress in Barcelona, Spain 1985, youth and development are the two sides that cannot be separated. While Rohmat (1998) according to the position of youth in society is a development agency plays an active role for the welfare of himself and of the surrounding society.

The development of a palm oil plantation in fact is economic development in rural oriented (Almasdi, 2004). The target development of the plantation sector was able to increase the income rural people. Thus, the poor people in the rural area can be reduced (Bungaran 2011; Almasdi, 2005). The purpose of palm plantation project is making agricultural commodities such as the superior program to achieve the welfare of society in the rural area.

The main commodities produced in district of Bandar Pasir Mandoge is Palm oil plantations. This can be seen form the extent of the palm plantation land in this area (Table 1). The high yield oil palm plantation land in district of Bandar Pasir Mandoge has made palm plantation sector become the main livelihood of the society in this rural.

TABLE 1. Land Area and the Results of the Production of Palm Plantation in Bandar Pasir Mandoge

\begin{tabular}{ccc}
\hline Years & $\begin{array}{c}\text { Land Area } \\
\text { (ha) }\end{array}$ & $\begin{array}{c}\text { Production } \\
\text { (ton) }\end{array}$ \\
\hline 2013 & 9.116 & $29.101,68$ \\
2014 & 9168 & $27.536,38$ \\
2015 & 9461 & $152.979,90$ \\
\hline \multicolumn{3}{c}{ Source : Asahan in Figure, 2016 }
\end{tabular}

Palm oil plantation activities in rural areas have opened job opportunities for people. Research result from Almasdi (2012), the palm plantation and process plant area availability of Fruit Fresh Bunches (FFB), local people's livelihoods are no longer limited to the primary sector, but has been expand efforts on the tertiary sector. The plantation in rural area make society have opportunities to become workers, farmers and entrepreneurs from this sector.

For the communities in Bandar Pasir Mandoge, economy activity in palm oil plantation area are base priority to improve the income and purchasing power of families. Because that the 
interest can encourage of youth society t this area more high day to day. According to Siradjuddin (2015), the benefits of palm plantation activities again social economic aspect include 1) increased welfare around society; 2) expand employment and opportunity of tryed; 3) contributes to regional development.

To achieve the welfare of youth in rural areas required the affect factor of welfare as a stimulus for the youth to achieve his welfare. Therefore, the factors affect the increasing welfare of the youth in palm oil plantation area of in this district will be examined from several indicators, such as economic status, then education, work experience and engage in the activities of youth organizations as well as the social status of youth in the society.

Youth society in rural area is the age of productive as workers in the palm oil plantation, besides the necessity requirement of sufficient condition between palm farmers and entrepreneurs, so FFB can distributed so that created the economic chain in the industrialization in the sector of palm oil plantation (Bungaran,2011). Thus the role of youth as workers, farmers and entrepreneurs in rural areas suspected to have a role in regional development in district of Bandar Pasir Mandoge.

\section{RESEARCH METHODOLOGY}

This research has conducted through quantitative analysis. Relationships between the variables examined are relationship or casual relationship between the factor that affect welfare of youth in Palm oil plantation area in district of Bandar Pasir Mandoge, Asahan Regency, Indonesia. Samples taken in the research area with used the formula from Slovin (Prasetyo, 2005). With a description of the overall " $n$ " is samples, "N" is the population number and "e" is the error rate of accuration sample $10 \%$ and $90 \%$ accuracy level. Sampling done in a stratified cluster sampling so that the nine rural in the district become samples is 94 respondents out of a total of 9 rural in Bandar Pasir Mandoge, Asahan Regency. The calculation results are presented in the table below :

\section{TABLE 2. Population and Sample Research}

\begin{tabular}{|l|c|c|c|c|c|c|c|}
\hline \multicolumn{1}{|c|}{ Rural } & \multicolumn{3}{|c|}{ Population } & \multicolumn{3}{c|}{ Samples } & Total \\
Sample \\
\hline Huta Padang & Entrepreneur & Worker & Farmer & Entrepreneur & Worker & Farmer & \\
\hline Huta Bagasan & 12 & 144 & 84 & 3 & 9 & 4 & 16 \\
\hline B.P. Mandoge & 13 & 168 & 98 & 3 & 5 & 3 & 11 \\
\hline Suka Makmur & 8 & 156 & 91 & 2 & 5 & 1 & 8 \\
\hline Sei Kopas & 6 & 72 & 42 & 2 & 5 & 3 & 10 \\
\hline Silau Jawa & 9 & 184 & 52 & 2 & 12 & 2 & 16 \\
\hline Sei Nadoras & 4 & 38 & 21 & 1 & 3 & 1 & 5 \\
\hline Tomuan Holbung & 10 & 120 & 70 & 2 & 4 & 3 & 9 \\
\hline Gotting Sidodadi & 7 & 190 & 49 & 1 & 5 & 3 & 9 \\
\hline Total & 83 & 1168 & 563 & 17 & 53 & 22 & 94 \\
\hline
\end{tabular}

Source :Primary Data, (2017)

The level of accuracy in the research is $95 \%$ $(\alpha=5 \%)$, and the data is assumed to be normal distribution. Primary data collection was conducted using a questionnaire that list was complied appropriate with research needs. To obtain accurate data of researcher using multiple linier regression analysis. This is to prove the relationship or no function or casual relationships between two or more independent variables with one dependent variable. Multiple liner regression equations used in this research are:

$$
Y=\beta_{0}+\beta_{1} X_{1}+\beta_{2} X_{2}+\beta_{3} X_{3}+\beta_{4} X_{4}+\beta_{5} X_{5}+\mu
$$

Description :
$\mathrm{Y} \quad$ = welfare of youth (income $(\mathrm{Rp}) \&$ outcome (Rp) Likert scale (1-5)

$\mathrm{X}_{1}=$ economic status (metier status) Likert scale (1-5)

$\mathrm{X}_{2}=$ Education (level of formal education) Likert scale (1-5)

$\mathrm{X}_{3} \quad=$ Experience (long/years), Likert scale (1-5)

$\mathrm{X}_{4} \quad=$ Youth organization (dummy: $1=$ Holding. $0=$ do not hold)

$\mathrm{X}_{5} \quad=$ Social status (Dummy: $1=$ youth figure $0=$ youth non figure)

$\beta_{0} \quad=$ Intercept

$\beta_{1-} \beta_{5}=$ coefficient regression

$\mu=$ error term 
Research is moving on from the hypothesis that the independent variable; economic status $\left(\mathrm{X}^{1}\right)$, education $\left(\mathrm{X}^{2}\right)$, experience $\left(\mathrm{X}^{3}\right)$, youth organization $\left(\mathrm{X}^{4}\right)$ and social status $\left(\mathrm{X}^{5}\right)$ simultaneously and partial effect on youth welfare in palm oil plantation area variable (Y) in the district. Then, the process research to reduce aberration caused by subjective elements, researcher then any finished logging the confirmation is done through a questionnaire interview. This is done to ensure that the data specified by the respondents are valid to use analysis.

\section{DISCUSSION}

Based on the result of the research that has been done, earned data about factors and the role of youth in the palm oil plantation area in Bandar Pasir Mandoge. Research conducted in nine rural at this sub-district. From 1802 population of respondent, there are 94 youth population that has been collected in this study.

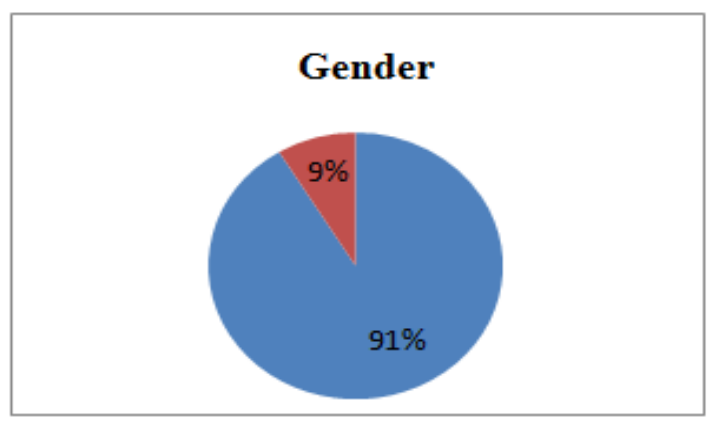

GRAPHICS 1. Gender and Age of Respondent

From the aspect of economic status of youth as workers is the most, they total 49 respondents, then followed the workers and farmers totalled 16 respondents, as farmers as 13 respondents, farmers and entrepreneurs 11 respondents and entrepreneurs are only 5 respondents. The distribution data looks that there are dual role of youth in the process of development in the palm oil planters area.

From the aspect of formal education of youth, the highest education there at the High

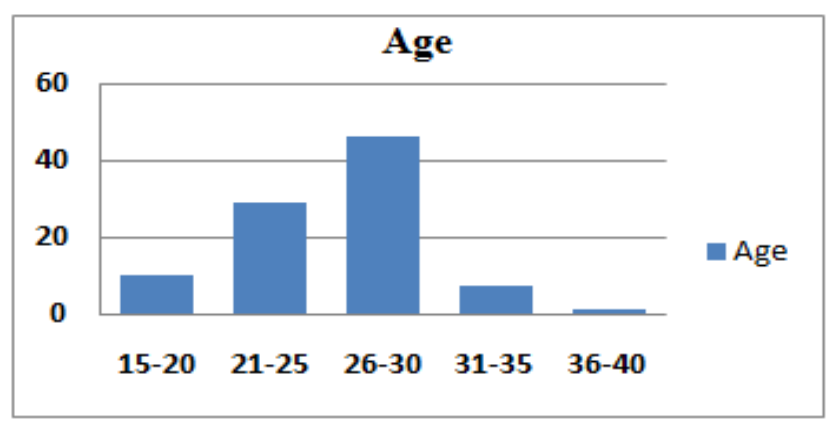

The youth data distribution have been collected from the profession of youth as workers, farmers and entrepreneurs in the palm oil plantations area. This section will discuss about the characteristic respondent, the affect factor influence the welfare of youth and the role of them in to development of the region in this area.

\section{A. Characteristic Respondent}

Based on the gender aspects of youth, there are male $(91 \%)$ and only $9 \%$ of female, youth of palm groves are dominated by men because of type of work in the palm oil plantation is an heavy work. Then, from the aspect of age, youth age 1520 years total 10 respondents, followed by youth age 21-25 total 29 , then youth aged 26-30 has the most respondent total 46, next youth aged 31-35 total 7 , as well as youth $36-40$ total just 1 respondent. A productive age of youth in this area is on quantity 26 up to 30 years. This is the age of maturity of the thoughts and experiences of youth in the management of palm plantation.

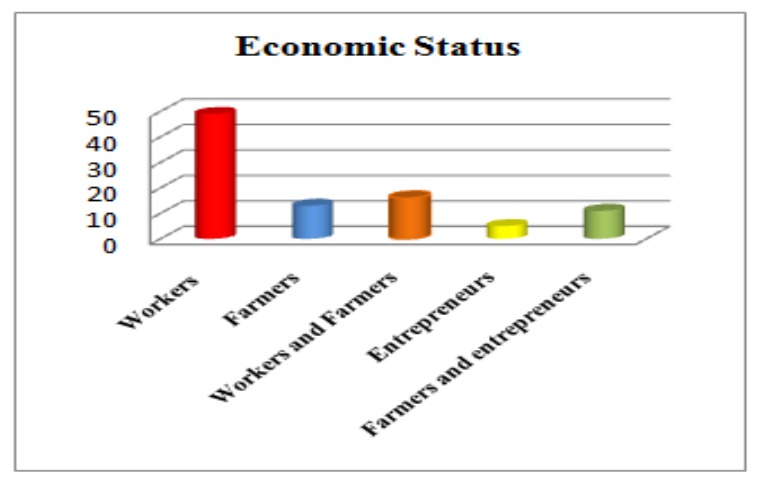

School totalled 39 respondents, then followed by Junior High School totalled 37, Elementary School totalled 14, No School 2 respondent and College totalled 2 respondent. Based on research on the location of the phenomenon, the level of education of youth affect their role in determining the attitude for the future. Youth who have low education always persist in hometown, while when the level of education of youths getting high then he chose to wander into the city.

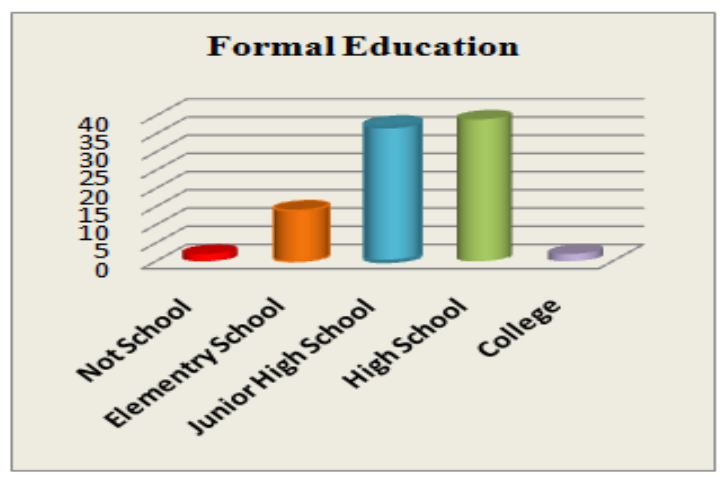

GRAPHIC 2. Economic Status and Formal Education of Respondent 
From the aspect of income and expenses of youth, the highest income and expenses has dominated of youth who have income start from $\mathrm{Rp}$ 100.000 up to Rp 2.000.000. It is show that 48 of a total 94 respondents still have low income. From the results of the review in this area shows that the increased income of youth in palm planters area are affected by the level of the profession, which means that the income of workers and farmers profession is definitely lower than the income from the entrepreneurs.
Based on Table 3 show that the level of income of youth in line with expenses. If the income moving up, then followed with a high expenses anyway. Many youth who still unmarried felt satisfied with their income, but not to the youth who are already married, many they felt dissatisfied with their income. This is because the cost of living between unmarried and married young men had different levels while the percentage of income among them almost the same.

TABLE 3. Income and Expenses of Youth

\begin{tabular}{ccccc}
\hline No. & $\begin{array}{c}\text { Income / Month } \\
\text { (Million, Rp) }\end{array}$ & $\begin{array}{c}\text { Totalled } \\
\text { Respondent }\end{array}$ & $\begin{array}{c}\text { Expenses / Month } \\
\text { (Million, Rp) }\end{array}$ & $\begin{array}{c}\text { Totalled } \\
\text { Respondent }\end{array}$ \\
\hline 1 & $0,1-2$ million & 48 & $0,1-1$ milion & 32 \\
2 & $>2-5$ million & 33 & $>1-2$ milion & 32 \\
3 & $>5-10$ million & 11 & $>2-3$ milion & 13 \\
4 & $>10-15$ million & 0 & $>3-5$ milion & 6 \\
5 & $>15$ million & 2 & $>5$ milion & 6 \\
& Total & 94 & & 94 \\
\hline & & Source: Primary Data $(2017)$
\end{tabular}

B. The Influence of Economic Status, Education, Experience, Youth Organizations and Social Status Against the Welfare of the Youth of Palm Planters in district of Bandar Pasir Mandoge.

Through multiple regression analysis, created the function equation factors affecting the welfare of the youth in Palm oil plantation area in district of Bandar Pasir Mandoge. The dependence variable such as the economic status, education, experience, youth organization and social status. The influence of dependent and independent variable have passed the test of validity and test assumptions classic so it deserves to be extended to test phases (f-test) is simultant and test (t-test) is partial.

To know how the variables are independent of the dependent variables simultaneously then used the f-test case. Where the value significance of $0,05>$ then double variable $\mathrm{X}$ to simultaneously have the effect on the variable $Y$

TABLE 4. Result of Simultant Test (F-test)

ANOVA $^{\mathrm{a}}$

\begin{tabular}{|c|c|c|c|c|c|}
\hline Model & Sum of Squares & Df & Mean Square & $\mathrm{F}$ & Sig. \\
\hline Regression & 260,492 & 5 & 52,098 & 19,891 &, $000^{\mathrm{b}}$ \\
\hline $1 \quad$ Residual & 225,247 & 86 & 2,619 & & \\
\hline Total & 485,739 & 91 & & & \\
\hline
\end{tabular}

a. Dependent Variable: Kesejahteraan

b. Predictors: (Constant), Social_Status, education, Status_organization, experience, economic_status

Based on the results of the statistical tests in the table note that significances is 0.00 value, less than 0.05. Then is can be concluse that the hypothesis was accepted. It means there is a simultaneous influence of independent variable i.e. economic status, education, experience, youth organizations and social status against the dependent variable i.e. youth welfare in this subdistrict. The accuration of the conclusions agains the test done in case value significance < of $\alpha=0.05$ then partially variable $\mathrm{X}$ has the effect on the variable Y. Simultaneous test results contained in the table below. 
TABLE 5. Result of Partial Test (t-test)

\begin{tabular}{|c|c|c|c|c|c|}
\hline \multirow[t]{2}{*}{ Model } & \multicolumn{2}{|c|}{$\begin{array}{c}\text { Unstandardized } \\
\text { Coefficients }\end{array}$} & $\begin{array}{r}\text { Standardized } \\
\text { Coefficients }\end{array}$ & \multirow[t]{2}{*}{$\mathrm{t}$} & \multirow[t]{2}{*}{ Sig. } \\
\hline & $\mathrm{B}$ & Std. Error & Beta & & \\
\hline (Constant) & $-1,556$ & 1,068 & & $-1,457$ &, 149 \\
\hline Economic_status &, 521 &, 085 &, 516 & 6,124 &, 000 \\
\hline Education &, 006 &, 216 &, 002 &, 030 & ,976 \\
\hline experience &, 372 &, 148 & ,203 & 2,509 &, 014 \\
\hline Organization_of Youth &,- 026 & ,402 &,- 005 &,- 065 &, 948 \\
\hline Social_Status & 1,059 &, 438 &, 212 & 2,420 &, 018 \\
\hline
\end{tabular}

a. Dependent Variable: Welfare

Based on the description of the table. The influence economic status variable significantly to the welfare of the youth of Palm planters in district of Bandar Pasir Mandoge, because income youth worker will be lower than the farmers and entrepreneurs. It is also followed by a youth worker spending lower than spending on farmers and entrepreneur. As the result, the lower income youth then getting little aces that the own in palm oil plantation management. Accessibility of youth are at the lowest Palm planters level workers, then the farmers in the middle level up to the highest level is a businessman.

The education variable do not affect significantly to the welfare of the youth of Palm planters. This condition happens because; the first phenomenon of background expertise field of formal education respondents do not comply with the expertise of the field work on a palm plantation management, which the Graduate School of mechanical engineering of youth or High School, but was proficient in managing the process of production and distribution of palm oil, for the second the phenomenon of high education levels encourage youth and migrated to urban areas to work in the sector in accordance with the educational background, un-influence of youth education factor against welfare was also influenced by aspects of the share no formal education and informal (daily activity) the youth.

Influence experience variable significantly to the welfare of the youth of palm planters, because experience is the informal education of youth lived during the running of activity and learning during life. The longer experience of youth on palm plantation management, then the higher level of their welfare. The young man who has been more parents will have a better experience than youth under age, experiences encourage youth to continue to increase income for the high their welfare.

Variable youth organizations do not affect significantly to the welfare of the youth of Palm planters. Because it does not sincronise in palm area youth activity of the youth in the youth organization. Youth activity in palm plantations discuses how to increase the income and purchasing power of youth to meet the needs of her life so that the welfare of youth are also rising, while activity on the youth organization dominated by religious based organization more discuss about religious events. Unsicronised the activity of youth and youth organizations of palm plantations to make youth more attention on plantation management activity sucked Palm, this beats the attraction activity in youth organizations so as to result in the lack of activities and work programme on youth organizations.

Influence of social status variables significantly to the welfare of the youth of Palm planters. Social status affect the level of youth to their welfare, where the higher the level of well-being of the community, then he is increasingly participate in the activity contained in the community and getting organised to provide donations on social activities that exist in their environment, then people start thinking and deciding to become active in the community so that he is known as community leaders.

\section{Realization of the role of Youth Palm Planters in managing Oil Plantation in Bandar Pasir Mandoge, Asahan Regency}

The role of youth in Bandar Pasir Mandoge, Asahan Regency on palm plantations management sector as local-workers, farmers and entrepreneurs have been able to play an important role inmaximizing the level of well being of himself that in the measure of economic status and income level as well as their expenses. In addition, the role of youth in the real has also been directly involved in the cycle of the economic chain from Palm oil plantation sector in this sub-district.

In the field of forestry, labour's position is a factor of production second only to land. Palm plantation youth worker role caring for palm, harvest and transport the Fresh Fruit Bunches (FFB), FFB results. The use of labor stated in the 
magnitudes of the outpouring of work day labour effectively utilised. From 48 the role of the workers there are 38 workers were paid monthly and 3 worker paid wholesale.

There is the young man has a dual role in increasing needs economy, one of them is a young man who plays the role of workers and farmers. As he performs the process af harvesting and transport and as farmers increase production and expand the land. The average young man who plays the role of farmers and planters of Palm was at the age of 27. This shows that awareness formed youth for increasingly more and increase its role in the management of palm plantation.

Entrepreneurs become important nodes in the area of development. They have an important role as the controlling wheel economy farmers and plantation worker of palm groves. Farmers and workers dependent on the role entrepreneurs full but entrepreneurs are also dependent on farmers and worker, so have been intertwined relationships that - need each other. Economic cycle starting from the process of FFB results distributed to peasant entrepreneurs, entrepreneurs manage distribution of FFB via the workers and then sell the FFB to plant oil palm.

The role of youth as a farmer and businessman is a representation of the dynamic of the development process in this district. The double role of them to do developed is only to increase revenues from the palm plantation sector. There are 11 respondents from the 94 samples serve as workers and employers. Their revenues range from Rp 7.909.000 and average their spending only Rp 4.431.818. This shows that they enjoy a decent life in general the relationship between economic abilities of youth in district of Bandar Pasir Mandoge, Asahan Regency is still strong. This appears to be from a relationship of mutual need and mutual benefit between the role of youth as workers, farmers and entrepreneurs. Where is the magnitude of the revenue revenuereceived between the youth depends very much of the turnaround of the economy and the productivity of each of them so as to provide benefits against the well-being of himself and of the local community.

The process of development in district of Bandar Pasir Mandoge, Asahan Regency there is inequality of income-between workers, farmers and entrepreneurs. This happens for several reasons, first the youth in this sub-district did not get the same opportunity to take part was the development process, for youth who come from low economy doesn't have enough land capital to expand palm plantations and become entrepreneurs, while the youth originating intermediate economic generally have a plantation family and economic circumstances are adequate,- therefore he used his opportunity to improve economy himself and his family.

\section{CONCLUSIONS AND SUGGESTIONS \\ a. Conclusion}

Close results of the driving factor of palm plantations youth welfare based on economic status $\left(\mathrm{X}^{1}\right)$, experience $\left(\mathrm{X}^{3}\right)$ and social status of youth $\left(\mathrm{X}^{5)}\right.$ partially effect significantly to the well-being of youth (Y), whereas the education factor $\left(\mathrm{X}^{2}\right)$ and youth organization $\left(\mathrm{X}^{4}\right)$ partially do not affect significantly to the welfare of youth in palm planters area but simultaneously the variable factors that have influence independent significantly to the welfare of youth in Bandar Pasir Mandoge.

Realization of the role of youth in the palm planters area focusing on the role of worker, farmers and entrepreneurs of palm plantations, have affected the economic turnaround and development in this district. The role of youth in this district have been able to maximize the level of well-being of himself that in the measure of the level of income as well as their expenses. Then through the role they each formed a state of interdependence and mutual benefit, where the magnitude of the income and production results being experienced farmers will also encourage the magnitudes of income of workers and employers. But in addition to these roles have occurred significant imbalances between the average income of workers, farmers and entrepreneurs youth Palm planters. Inequality occurs because these young men do not get the same opportunity to take part in the construction-caused by economic background and the -welfare of youth.

\section{b. Suggestion}

To enhance the role of youth in the palm plantation management and the improvement of the welfare of the youth of palm planters (case studies Sub Bandar Pasir Mandoge Asahan Regency) then suggested :

1. Local Governments to optimize the role of youth based on economic status, social status, and experience to improve the welfare of local youth and push economic growth to the general public.

2. The need to increase program participation of youth nomads to return to the village by applying the quote "marsipature hutana 
$b e^{l}$, in palm plantations management sector.

3. The need for training and development program to the youth workers of the Palm and palm growers so driven to become entrepreneurs, so the income of youth workers and farmers are able to increase.

\section{REFERENCE}

[1] Badrudin, Rudi. "Ekonomi Otonimi Daerah". Yogyakarta. UPP STIM YKPN. 2012.

[2] Almasdi Syahza. "Pemberdayaan Ekonomi Masyarakat Perdesaan Melalui Pengembangan Industry Hilir Berbasis Kelapa Sawit Di Daerah Riau". Jurnal Sosiohumaniora, Vol.6, No.3. 2004.

[3] Almasdi Syahza. "Percepatan Ekonomi Pedesaan Melalui Pembangunan Perkebunan Kelapa Sawit". Jurnal Ekonomi Pembangunan, Vol. 12, No. 2, December 2011, pg. 297-310. 2011

[4] Avianti Annisa \& Martua Sihaloho. "The Role of Child Labour in Small Industry of Sandals for Their Household Income and Children's Welfare". Sodality: Journal Sosiologi dan Pedesaan. Pg/ 10-25 2013.

[5] Irsyadi Siradjuddin. The Impact of Plantation Development in the Economic Regional in Rokan Hulu District. Jurnal Agroteknologi, Vol. 5, No.2. Februari 2015

[6] Rambe, Armaini, The Analysis of Family Expenditure Allocation and Welfare (A Study at the Sub-District of Medan City, North Sumatera. January 2008.

[7] Rohmad, Zaini. "Role of Youthin the development of Rural Society". IPB. Bogor. 1998.

[8] Saragih, Bungaran. "Suara Dari Bogor; Membangun Sistem Agribisnis". Bogor: Yayasan USE. 2001a.

[9] Setyamidjaja. Palm oil. Bogor. IPB. (2006).

[10] Sirojuzilam. "Pembangunan Ekonomi Regional". Medan. USU Press. 2015

[11] Theresia, A, Et. "Pembangunan Berbasis Masyarakat". Bandung, Alfabeta. (2014)

[12] Todaro, Michael P. "Economic Development in the Third World. Seven Edition”. Jakarta Erlangga. 2000.

[13] Todaro, Ctephen C. Smith. "Econom ic Development (Nine Edition, Jilid I)". Jakarta. Erlangga. 2006.

[14] Yunita, Erma, Et. "Effect of Development of Oil Palm on Rural Economy in the District Fullnes District Rokan Hulu". University of Riau. Un-name year.

\footnotetext{
${ }^{1}$ Marsipature huta na be is the slogan which is embedded to the community and the Government of North Sumatra which means Let's fix the respective home villages or the actual extension of meaning to come back to the village and built the village.
} 